\title{
CREBBP Gene Mutation
}

National Cancer Institute

\section{Source}

National Cancer Institute. CREBBP Gene Mutation. NCI Thesaurus. Code C132227.

A change in the nucleotide sequence of the CREBBP gene. 